\title{
SOSIO-EKOLOGI MASYARAKAT SEKITAR SABUK HIJAU (GREENBELT) WADUK JATIGEDE
}

Socio-Ecology of Civil Society at Green Belt of The Jatigede Reservoir

\author{
Anita Budiyanti \\ Penyuluh Kehutanan di Cabang Dinas Kehutanan Wilayah IX \\ J1. Serma Muchtar No. 123 Sumedang \\ Dinas Kehutanan Provinsi Jawa Barat \\ Email : gwnitnot@gmail.com
}

\section{Diterima 13 September 2018/Disetujui 10 Oktober 2018}

\begin{abstract}
Green Belt area of the Jatigede Reservoir are located at an elevation of 260-262.5 masl covering 5 administrative districts namely Jatigede, Jatinunggal, Wado, Darmaraja and Cisitu. Spatialy is included into a local protected area which one the ownership of land is under the authority of the reservoir management. The phenomenon that occurred earlier in the dams in Indonesia are the green belt fields has degradation such as occupational settlement and conversion of agricultural land by civil society which does not convey the principles of soil and water conservation. Green belt area as buffer zone and an interface between the core zone (aquatic) and the outside of reservoir area (community settlement). The socioecological interaction between human and natural resources will always occur in the buffer zone. The object of this research is to learn of socio-ecology at green belt land as multifunctional area both for conservation and production function and in its utilization involving people affected by the construction of Jatigede dam. The method used is a concurrent quantitative-qualitative combination to explore the biophysical, social, economic and cultural characteristics and perception of the stakeholders about exictence the green belt of the Jatigede dam. The socio-ecology of civil society not use concept in land use plan green belt of jatigede reservoir is to make zonation based on biophysical factor that is zones of conservation and production.
\end{abstract}

Keywords : Green belt, Jatigede Reservoir, Socio-ecology landscape 


\section{PENDAHULUAN}

Pembangunan waduk selain mempunyai manfaat yang besar juga telah mengorbankan beberapa kepentingan, diantaranya adalah mengurangi lahan garapan masyarakat dan menyebabkan pergeseran/perubahan mata pencaharian masyarakat yang terkena dampak. Hal ini telah menyebabkan tekanan penduduk terhadap lahan di sekitarnya meningkat yang dikhawatirkan dapat mengganggu terhadap kelangsungan waduk (keberadaan sabuk hijau) dan berpengaruh terhadap lingkungan alam.

Adanya tekanan penduduk yang tinggi di kawasan waduk Jatigede dikhawatirkan akan berdampak pada kelangsungan sabuk hijau waduk Jatigede. Salah satu cara untuk menanggulangi hal tersebut adalah dengan melakukan penataan ruang kawasan waduk Jatigede, termasuk dalam merencanakan konsep pemanfaatan daerah sabuk hijau waduk Jatigede.

Pembangunan waduk Jatigede menyebabkan tergenangnya 28 desa dari 5 Kecamatan yaitu Kecamatan Jatigede (5 desa), Jatinunggal (2 desa), Wado (4 desa), Darmaraja (13 desa) dan Cisitu (4 desa). Dari 28 desa yang terdampak, ada 6 (enam) desa di 3 Kecamatan yang hilang akibat genangan, yaitu desa Sukakersa (Jatigede); Padajaya (Wado); Cipaku, Leuwihideung, Cibogo dan Jatibungur (Darmaraja) yang terlihat pada peta lokasi penelitian. Lahan yang terkena dampak genangan berdasarkan penggunaannya adalah lahan penduduk seluas 3.591 ha yang terdiri dari permukiman dan pertanian, sedangkan lahan berupa kawasan hutan seluas 1.389,3 ha (Bappeda Kabupaten Sumedang, 2015).

Pembangunan waduk Jatigede mengakibatkan letak/posisi desa-desa ada yang berbatasan langsung atau berada di tepian air waduk. Padahal sempadan waduk merupakan area sabuk hijau (greenbelt) yang dapat ditinjau dari 4 aspek yaitu, aspek fisik untuk pengamanan bendungan (kelestarian waduk), aspek sosial yaitu memberikan manfaat bagi masyarakat, aspek ekonomi yaitu memberikan manfaat secara finansial (sebagai sumber pencaharian masyarakat) dan aspek estetika sebagai suatu lanskap yang tertata (untuk dijadikan pariwisata).

Terjadinya degradasi lingkungan fisik dipicu oleh faktor utama yang berasal dari aspek sosial ekonomi. Berdasarkan studi pendahuluan kepada Satker pembangunan proyek Waduk Jatigede, didapatkan informasi bahwa keterlibatan masyarakat dalam kegiatan pemanfaatan daerah sabuk hijau masih tahap pengkajian. Penelitian ini diharapkan dapat mengetahui dan mendeskripsikan karakteristik sosio-ekologi daerah sabuk hijau (greenbelt) Waduk Jatigede di Desa Karang Pakuan dan Desa Ciranggem, sehingga dapat menjadi masukan dalam implementasi kebijakan yang dibuat nanti. Pendekatan sosio-ekologi digunakan karena adanya integrasi antara aspek sosial (ekonomi dan budaya) dengan aspek 
ekologi dalam merencanakan konsep pemanfataan sabuk hijau sebagai suatu ruang yang multifungsional (fungsi lindung/konservasi maupun produksi), yaitu dengan menggunakan perencanaan lansekap.

\section{METODE PENELITIAN}

Penelitian ini dilakukan selama selama 7 bulan, mulai dari bulan Oktober 2016 sampai dengan bulan April 2017. Lokasi penelitian dilaksanakan di kawasan Waduk Jatigede, yaitu Desa Cirangggem, Kecamatan Jatigede dan Desa Karang Pakuan, Kecamatan Darmaraja, Kabupaten Sumedang, Jawa Barat.

Pengumpulan data dilakukan dengan wawancara semi terstruktur (semi structured interview method) dan mendalam (in-depth interview). Informan terdiri dari: SNVT Pembangunan Waduk Jatigede, Bappeda, Dinas Kehutanan dan Perkebunan, Perum Perhutani, dan Akademisi. Teknik penarikan sampel yang dilakukan ada dua tahap (Riduwan dan Kuncoro, 2011) yaitu :

1) Berdasarkan probability sampling secara simple random sampling.

Penentuan jumlah sampel menggunakan rumus Taro Yamane sebagai berikut :

$$
\mathrm{n}=\frac{\mathrm{N}}{\mathrm{Nd}^{2}+1}
$$

Keterangan :

$\mathrm{N}$ = Ukuran sampel

$\mathrm{N}=$ Ukuran populasi (Jumlah Penduduk Desa Karang Pakuan dan Desa Ciranggem)

$\mathrm{D}=$ sampling error $10 \%$

Penentuan ukuran sampel dari populasi 7.451 orang dengan rumus ini diperoleh 98,67 dibulatkan menjadi 99 responden.

2) Berdasarkan proportional sampling. Dari jumlah sampel responden yang telah ditemukan pada tahap I kemudian ditentukan jumlah masing- masing sampel setiap desa, dengan rumus sebagai berikut :

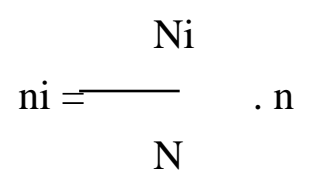

Keterangan :

$\mathrm{ni}=$ Ukuran sampel menurut stratum

$\mathrm{n}=$ Ukuran sampel seluruhnya 
$\mathrm{Ni}=$ Ukuran populasi menurut stratum

$\mathrm{N}=$ Ukuran populasi seluruhnya

Analisisi data dilakukan dengan kuantitatif dan kualitatif. Data kuantitatif diperoleh melalui kuisioner terhadap responden mengenai keadaan sosial ekonomi masyarakat di lokasi penelitian yang dianalisis secara statistik sederhana dan disajikan dalam bentuk bagan, tabel dan/atau grafik. Data kualitatif diperoleh dari informan kunci (Bappeda, Dinas Kehutanan dan Perkebunan, Perum Perhutani, SNVT Proyek Pembangunan Jatigede, Akademisi) dan hasilnya dianalisis deskriptif untuk mengetahui arahan rencana pemanfaatan, keinginan dan preferensi pihak-pihak yang berkepentingan terhadap keberadaan daerah sabuk hijau, yaitu masyarakat sebagai pelaku utama, otorita pengelola waduk Jatigede, serta pemerintah daerah melalui instansi terkait sebagai pemangku kebijakan daerah setempat.

\section{HASIL DAN PEMBAHASAN}

\section{Karakteristik Sosioekologi Daerah Sabuk Hijau Waduk Jatigede}

Kondisi ekologi kawasan sabuk hijau Waduk Jatigede di dua desa penelitian dari beberapa parameter, yaitu bentuk lahan, kelerangan, jenis kesuburan, curah hujan, dan kondisi tanah terlampir pada Tabel 3 dan 4. Parameter-parameter tersebut dapat mempengaruhi terhadap kondisi sosial masyarakat sekitarnya, seperti kelerengan mempengaruhi terhadap pola pemanfaatan lahan sabuk hijau, semakin curam kelerengan maka pemanfaatan sabuk hijau hanya untuk fungsi lindung/konservasi, tidak untuk kegiatan produksi/budidaya. Semakin miring permukaan tanah dari bidang horizontal, maka semakin banyak lapisan tanah bagian atas yang tererosi (Arsyad, 2000 dalam Saribun, 2007).

Waduk Jatigede keberadaanya sebagai daerah penyangga yang membatasi aktivitas antara zona inti (perairan) dengan zona daratan (pemukiman masyarakat). Sabuk hijau sebagai sumber daya alam memiliki fungsi tidak hanya untuk menjaga kelestarian waduk, tetapi juga harus bisa dimanfaatkan untuk kesejahteraan masyarakat.

Pengetahuan masyarakat mayoritas hanya sedikit tahu mengenai keberadaan dan fungsi sabuk hijau Jati Gede. Desa Karang Pakuan 47,3\% dan Desa Ciranggem 47,86\% (Gambar 1 dan Gambar 2). Pengetahuan masyarakat mengenai sabuk hijau dari segi definisi dan fungsi mempunyai peran penting dalam menjaga keberadaan dari sabuk hijau. 
Tabel 3. Karakteristik sosioekologi sabuk hijau Desa Karang Pakuan

\begin{tabular}{|c|c|}
\hline Karakteristik Sosioekologi & Sabuk Hijau Desa Karang Pakuan \\
\hline Luas $(\mathrm{Ha})$ & 26,31 \\
\hline Bentuk Lahan & Datar - Bergelombang \\
\hline Kelerengan & Datar - Agak Curam \\
\hline Jenis/Kesuburan Tanah & Mediteran/Sedang \\
\hline Curah Hujan & $3.000-3.500 \mathrm{~mm} / \mathrm{tahun}$ \\
\hline Rawan Gerakan Tanah & Rendah - Menengah \\
\hline Penggunaan/Tutupan Lahan & Belukar/semak, Kebun, Sawah tadah hujan \\
\hline Kondisi sempadan waduk/tepian & Tidak ada vegetasi/terbuka - tutupan vegetasi kecil \\
\hline Pola usahatani & sawah, tumpang sari, hutan rakyat, kebun campuran \\
\hline $\begin{array}{l}\text { Tanaman/komoditas utama yang } \\
\text { dibudidayakan }\end{array}$ & $\begin{array}{l}\text { - Semusim : Padi, Jagung, Kacang Tanah, Ubi Kayu, } \\
\text { Kacang Panjang, Cabe, Pisang }\end{array}$ \\
\hline & $\begin{array}{l}\text { - MPTS : Alpukat, Mangga, Rambutan, Sawo, Petai, } \\
\text { Nangka, Kelapa, Bambu, Aren }\end{array}$ \\
\hline $\begin{array}{l}\text { Jenis ternak besar yang } \\
\text { dibudidayakan }\end{array}$ & $\begin{array}{l}\text { ' Domba : } 82 \text { ekor }(16,40 \%) \text { ke-3 terbanyak dari total } \\
\text { populasi domba di Kec. Darmaraja }\end{array}$ \\
\hline & $\begin{array}{l}\text { ' Sapi potong : } 86 \text { ekor }(16,44 \%) \text { ke-3 terbanyak dari } \\
\text { total populasi sapi potong di Kec. Darmaraja }\end{array}$ \\
\hline \multirow[t]{3}{*}{ Penduduk } & - Jumlah penduduk : 4.282 jiwa \\
\hline & $\begin{array}{l}\text { - Mata pencaharian mayoritas sektor pertanian } \\
(45,83 \%)\end{array}$ \\
\hline & - Tingkat pendidikan mayoritas tamatan SD (35\%) \\
\hline Kelompok Tani Hutan (KTH) & Mekar Pakuan \\
\hline
\end{tabular}

- Beberapa aktifitas yang dilakukan oleh masyarakat di lahan sabuk hijau Waduk Jatigede (Gambar 3 dan Gambar 4) dari 57 responden masyarakat Desa Karang Pakuan sebagian besar sebagai petani $(35,09 \%)$ dengan memanfaatkan lahan sabuk hijau yang sebagian besar statusnya sudah diganti rugi (pembebasan lahan) oleh SNVT. Pemanfaatan lahan diperuntukkan budidaya pertanian tanaman semusim, seperti jagung, kacang tanah, ubi jalar, ketela pohon, pisang dan cabai. Kegiatan lainnya adalah berjualan di tepian waduk Jatigede sebanyak 28,07\%, mencari rumput sebesar $21,05 \%$ dan aktifitas mengambil ikan (memancing) sebanyak 15,79\%.

Kondisi masyarakat Desa Ciranggem dari 42 responden melakukan budidaya pertanian sebesar 54,76\%, mencari rumput sebanyak 28,57\% dan mengambil ikan (memancing) sebanyak 16,67\%. Aktifitas budidaya pertanian yang dilakukan di lahan sabuk hijau berupa budidaya padi di sawah tadah hujan, serta budidaya tanaman semusim/palawija seperti pisang, jagung, ketela pohon, kacang tanah dan kacang panjang. 
Tabel 4. Karakteristik Sosioekologi Sabuk Hijau Desa Ciranggem

\begin{tabular}{|c|c|}
\hline Karakteristik Sosioekologi & Sabuk Hijau Desa Ciranggem \\
\hline Luas (Ha) & 50,85 \\
\hline Bentuk Lahan & Datar-Bergelombang \\
\hline Kelerengan & Datar-Curam \\
\hline Jenis/Kesuburan Tanah & Mediteran/Sedang \\
\hline Curah Hujan & $2.500-3.000 \mathrm{~mm} /$ tahun \\
\hline Rawan Gerakan Tanah & Rendah - Menengah \\
\hline Penggunaan/Tutupan Lahan & $\begin{array}{l}\text { Belukar/semak, Kebun, Hutan, Sawah tadah hujan, } \\
\text { tegalan/lading }\end{array}$ \\
\hline $\begin{array}{l}\text { Kondisi sempadan waduk/tepian } \\
\text { Pola usahatani } \\
\text { Tanaman/komoditas utama yang }\end{array}$ & $\begin{array}{l}\text { Tidak ada vegetasi/terbuka - tutupan vegetasi penuh } \\
\text { sawah, tumpang sari, hutan rakyat, kebun campuran } \\
\text { - Semusim : Padi, Jagung, Kacang Tanah, Ubi Kayu, }\end{array}$ \\
\hline dibudidayakan & $\begin{array}{l}\text { Kedelai, Kacang Panjang, Mentimun, Cabe, Pisang, } \\
\text { Kapolaga } \\
\text { - MPTS : Mangga, Rambutan, Petai, Nangka, Kelapa, } \\
\text { Bambu, Aren }\end{array}$ \\
\hline $\begin{array}{l}\text { Jenis ternak besar yang } \\
\text { dibudidayakan }\end{array}$ & $\begin{array}{l}\text { - Domba : } 1.161 \text { ekor }(17,05 \%) \text { ke- } 2 \text { terbanyak dari } \\
\text { total populasi domba di Kec. Jatigede }\end{array}$ \\
\hline & $\begin{array}{l}\text { - Sapi potong : } 244 \text { ekor }(17,78 \%) \text { ke-3 terbanyak dari } \\
\text { total populasi sapi potong di Kec. Jatigede } \\
\text { - Kambing : } 62 \text { ekor }(2,95 \%)\end{array}$ \\
\hline \multirow[t]{3}{*}{ Penduduk } & $\begin{array}{l}\text { - Kerbau : } 19 \text { ekor }(63.33 \%) \text { terbanvak dari total } \\
\text { ' Jumlah penduduk : } 3.162 \text { jiwa }\end{array}$ \\
\hline & $\begin{array}{l}\text { - Mata pencaharian mayoritas sektor pertanian : } 668 \\
\text { jiwa }(62,37 \%)\end{array}$ \\
\hline & $\begin{array}{l}\text { ' Tingkat pendidikan mayoritas tamatan SD } 1.031 \\
\text { jiwa }(66,34 \%)\end{array}$ \\
\hline Kelompok Tani Hutan (KTH) & Mekar Mulya \\
\hline
\end{tabular}

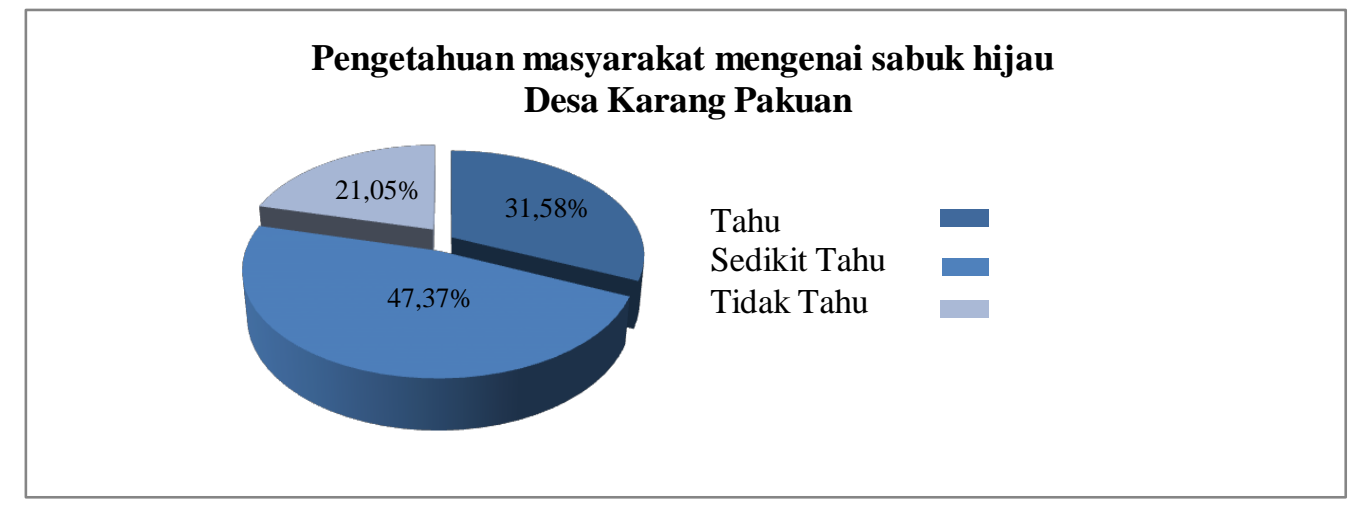

Gambar 1. Pengetahuan Masyarakat Mengenai Sabuk Hijau (Greenbelt) Desa Karang Pakuan 


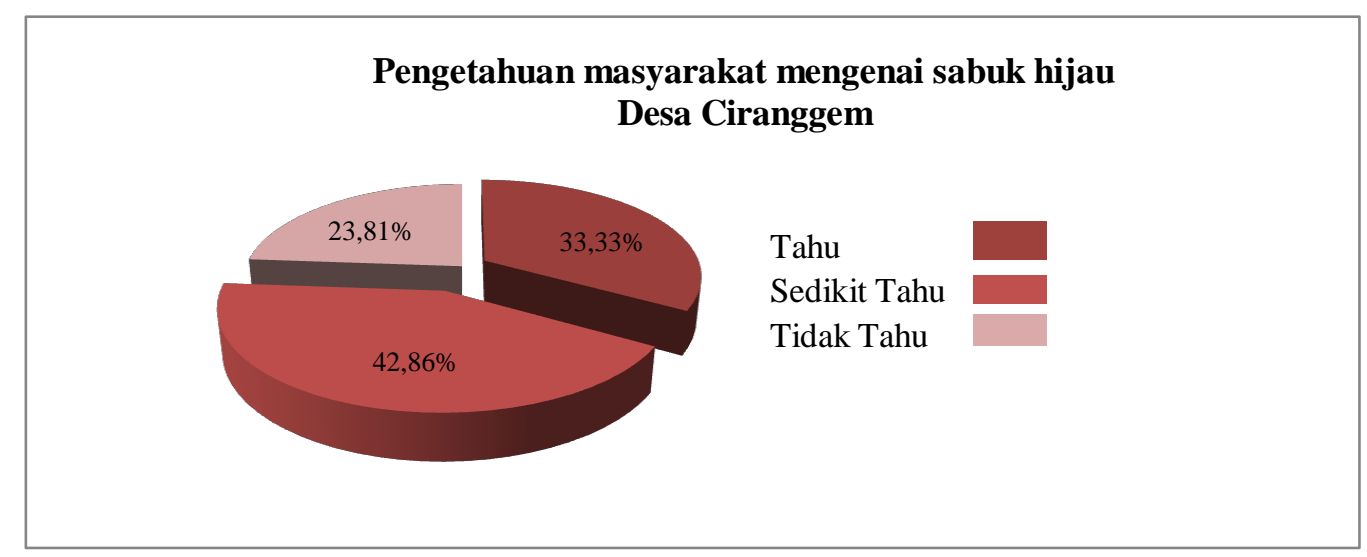

Gambar 2. Pengetahuan Masyarakat Mengenai Sabuk Hijau (Greenbelt) Desa Ciranggem

Menurut Marsetyo (2008) konsep feed/forage budgetting dapat diterapkan dengan asumsi masyarakat pemilik ternak hanya memberikan hijauan sebagai pakan tunggal (sistem cut and carry), sehingga dapat menentukan luas lahan yang dibutuhkan untuk ditanami hijauan pakan ternak. Kebutuhan pakan hijauan per ekor sapi setara dengan $6 \mathrm{~kg}$ bahan kering (BK)/hari (Marsetyo 2003 dalam Marsetyo 2008) dan kebutuhan pakan hijauan domba per ekor adalah $5 \mathrm{~kg}$ BK/hari (Murtidjo 1992 dalam Kushartono 2005).

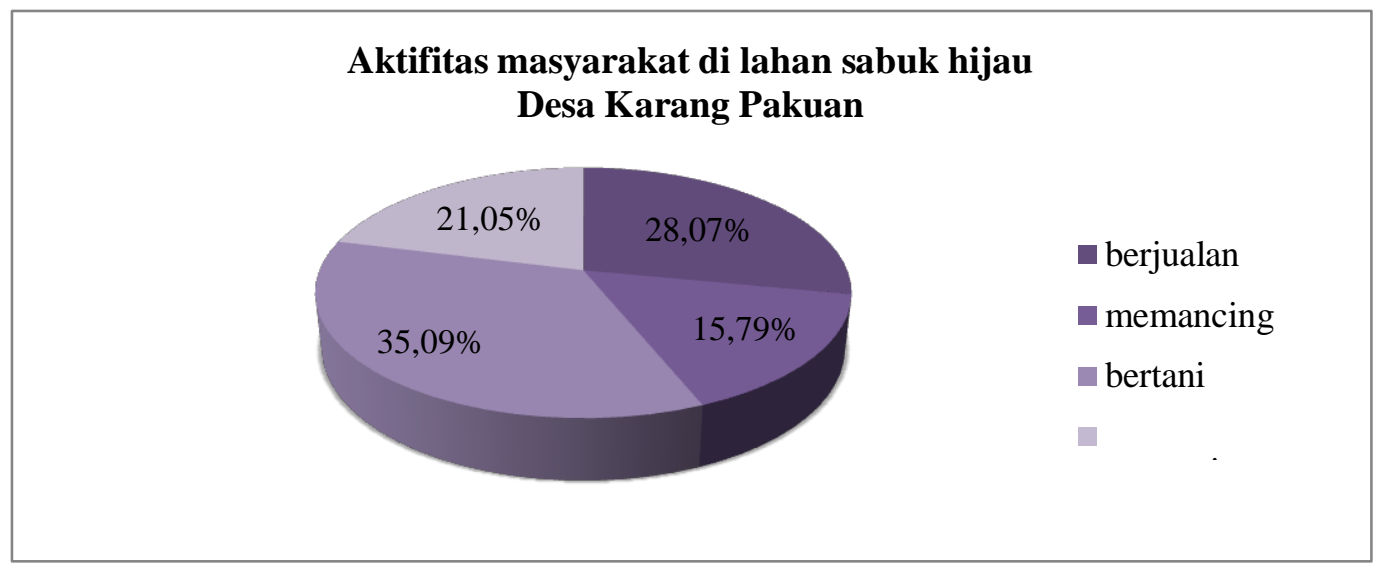

Gambar 3. Aktifitas masyarakat yang dilakukan di lahan sabuk hijau Waduk Jatigede Desa Karang Pakuan

Aktifitas mengambil ikan (memancing) juga banyak dilakukan di tepian air waduk Jatigede oleh masyarakat sekitar maupun masyarakat pengunjung. Kegiatan mengambil ikan (memancing) di zona perairan waduk Jatigede banyak dilakukan oleh masyarakat, mengingat potensi populasi ikan di kawasan waduk Jatigede terbilang melimpah. Program penebaran benih ikan telah banyak dilakukan baik oleh pemerintah Provinsi Jawa 
Barat maupun Pemerintah Daerah kabupaten Sumedang sejak dimulainya penggenangan kawasan Waduk Jatigede awal bulan Desember tahun 2015.

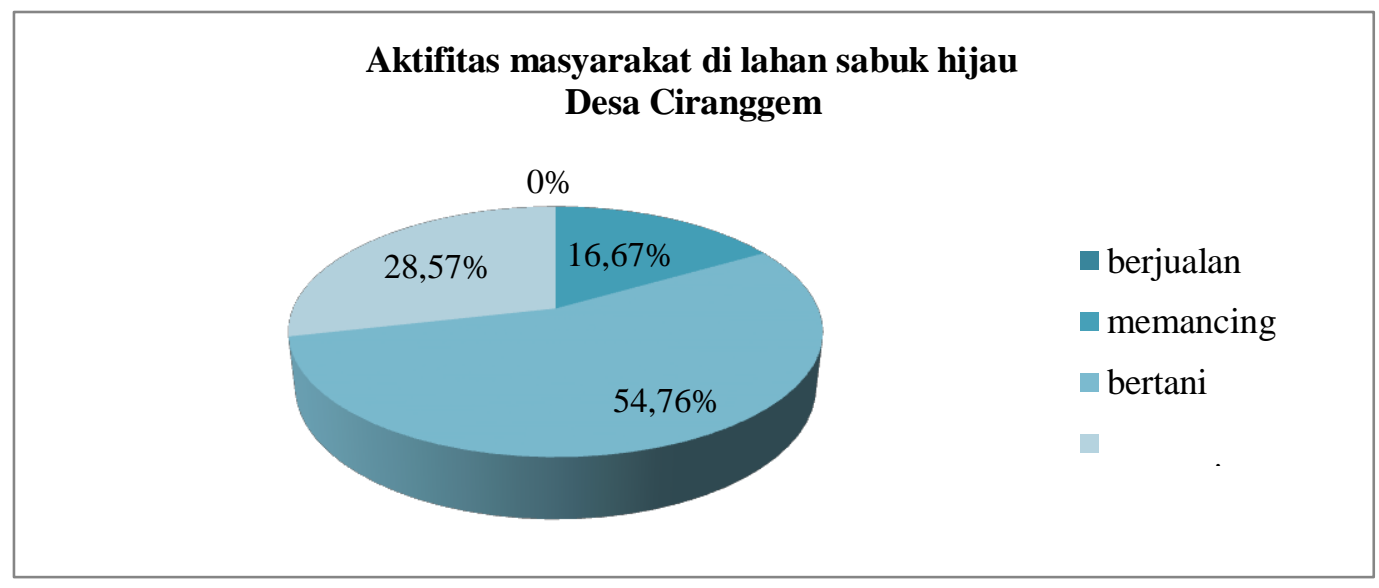

Gambar 4. Aktifitas masyarakat yang dilakukan di lahan sabuk hijau Waduk Jatigede Desa Ciranggem

Fenomena di daerah sabuk hijau menunjukan adanya peralihan mata pencaharian masyarakat sebelum adanya pembangunan Waduk Jatigede dari semula petani sawah/kebun/hutan, dan setelah adanya pembangunan Waduk Jatigede menjadi nelayan/pencari ikan, pedagang yang berjualan di sekitar tepian waduk, serta menjadi buruh/serabutan. Hilangnya sumber daya lahan (terrestrial) berganti dengan munculnya sumber daya air (aquatic) menjadi peluang menciptakan lapangan pekerjaan sektor perikanan melalui budidaya KJA sebagai mata pencaharian pengganti (Soemarwoto 1983 dalam Suwartapradja 2012).

Masyarakat di kawasan Waduk Jatigede yang berganti mata pencaharian dari petani lahan darat menjadi nelayan adalah yang mempunyai keterampilan menangkap ikan dan mempunyai modal untuk membeli peralatan menangkap ikan, seperti : perahu, jaring tangkap, dan alat pancing. Mereka berganti pekerjaan menjadi petani ikan sistem tangkap, karena kegiatan budidaya Keramba Jaring Apung (KJA) dilarang dilakukan di Waduk Jatigede, sesuai tercantum dalam Peraturan Daerah No.2 Tahun 2012 tentang RTRW Kabupaten Sumedang pasal 49 "pelarangan kegiatan jaring apung di badan air Waduk Jatigede".

Perubahan mata pencaharian dan tingkat pendapatan masyarakat merupakan dampak sosial dari pembangunan Waduk Jatigede. berdasarkan hasil observasi ketidakpastian tingkat pendapatan masyarakat karena jenis mata pencaharian yang belum ditekuni secara tetap seperti menjadi buruh 
bangunan, pada saat Waduk Jatigede digenangi, banyak warga terdampak yang berpindah secara mandiri membangun rumah baru sehingga lapangan pekerjaan sebagai buruh bangunan saat itu sangat dibutuhkan dan upah buruh menjadi melonjak tinggi. Pada keadaan normal upah buruh bangunan sekitar Rp. 50.000-75.000/hari menjadi Rp. 80.000-100.000/hari. Sedangkan yang beralih mata pencaharian menjadi nelayan ikan tangkap tergantung kepada hasil tangkapan, biasanya mereka mendapatkan hasil ikan 1-2 kg/hari dengan harga jual Rp. 20.000- 25.000/kg. Menurut Suriadi, dkk (2014) dalam kajian sosial ekonomi OTD Waduk Jatigede bahwa besaran biaya hidup warga di kawasan Waduk Jatigede adalah rentang Rp. 1.382.483 - Rp. 2.202.614 per KK/bulan dengan rata-rata sebesar Rp. 1.804.019 per KK/bulan atau Rp. 3.703 .002 per KK/bulan (dengan inflasi 1 th $=1,87)$. Untuk dapat memenuhi kebutuhan hidupnya masyarakat harus mempunyai penghasilan dengan besaran yang dapat menutupi besaran kebutuhan hidup yaitu rata-rata sekitar Rp. 60.134 per KK/hari atau Rp. 123.433 per KK/hari (dengan inflasi) secara kontinu, karena kebutuhan hidup tidak bisa ditangguhkan.

Masyarakat yang beralih mata pencaharian menjadi berjualan di tepi waduk Jatigede, karena adanya genangan air waduk menjadi daya tarik tersendiri untuk pengunjung yang sekedar ingin berwisata melihat Waduk Jatigede atau bertujuan memancing, baik yang berasal dari dalam maupun luar Kabupaten Sumedang. Berdasarkan hasil observasi besaran pendapatan masyarakat yang beralih mata pencaharian dengan berjualan di tepi waduk adalah sekitar Rp. 20.000/hari kalau sedang sepi pengunjung, dan sampai Rp. 300.000/hari kalau sedang ramai pengunjung yaitu pada hari minggu atau hari libur nasional. Terciptanya spot-spot wisata secara spontan mengakibatkan terciptanya peluang usaha seperti berjualan makanan, sewa perahu untuk keliling area perairan Waduk Jatigede dan sebagai penjaga parkir kendaraan. Spot-spot wisata di sekitar tepian air Waduk Jatigede yang sudah banyak dikunjungi dengan akses jalan yang baik diantaranya adalah : Tanjung Duriat (Desa Pajagan-Kecamatan Cisitu), Puncak Damar (Desa Pakualam-Kecamatan Darmaraja), Kapunduhan (Desa SukaratuKecamatan Darmaraja), Pasir Tugaran (Desa Karang Pakuan-Kecamatan Darmaraja), Panenjoan (Desa Jemah-Kecamatan Jatigede) dan Tegal Jarong (Desa Cijeungjing-Kecamatan Jatigede). Pengelolaan spot wisata tersebut diatas beragam yaitu ada yang oleh Perum Perhutani KPH Sumedang (Puncak Damar dan Tanjung Duriat), Pemerintahan Desa (Tegal Jarong, Panenjoan, Kapunduhan dan Pasir Tugaran). 
Spot-spot wisata yang dikelola oleh pemerintahan desa dan karang taruna adalah lahan milik desa seperti Tegal Jarong dan Panenjoan, sedangkan lahan milik otorita Waduk Jatigede adalah di Pasir Tugaran dan Kapunduhan dan termasuk kedalam peruntukan lahan sabuk hijau. Spot wisata lainnya yaitu Puncak Damar dan Tanjung Duriat yang berada diluar dan berbatasan langsung dengan daerah sabuk hijau. Kondisi eksisting lahan sabuk hijau yang menjadi spot wisata merupakan fenomena yang tidak bisa dicegah, sebelum kegiatan penataan sabuk hijau Waduk Jatigede dilaksanakan. Pada umumnya spot-spot wisata yang banyak dikunjungi yaitu sudah mempunyai akses jalan/infrastrukturnya baik, dimana sebagian besar berada di Kecamatan Darmaraja, sedangkan untuk Kecamatan Jatigede belum banyak dikunjungi karena terkendala akses jalan lingkar timur yang masih dalam tahap pembangunan.

Hasil wawancara dengan Disparbudpora, Pemkab Sumedang telah mengajukan 9 (sembilan) desa yang berada di pesisir bendungan Jatigede untuk menjadi desa wisata kepada Kementrian Pariwisata, yaitu Desa Cijeungjing, Cipicung, Jemah, Ciranggem, Mekarasih (Kec. Jatigede), Desa Pawenang (kec. Jatinunggal), Desa Sukaratu, Pakualam dan Karang Pakuan (Kec. Darmaraja). Kesembilan desa tersebut secara geografi berpotensi untuk ditata sehingga memiliki daya tarik sebagai desa wisata.

Kelembagaan yang berada di daerah sabuk hijau Waduk Jatigede selain Kelompok Tani Hutan adalah Kelompok Masyarakat Pengawas (POKMASWAS), yang dibentuk dengan tujuan meningkatkan partisipasi masyarakat dalam pengawasan dan pengendalian sumber daya perikanan serta menumbuh kembangkan siswasmas (sistem pengawasan masyarakat) agar selalu tertanam tanggungjawab dan rasa memiliki terhadap sumber daya perikanan. Pokmaswas terdiri dari tiap unsur tokoh masyarakat, tokoh agama, tokoh adat, LSM, nelayan, petani ikan serta masyarakat lainnya. Pokwasmas berada dibawah binaan Dinas Perikanan dan Peternakan, untuk tingkat pelaksanaan di lapangan dibawah bimbingan Penyuluh Perikanan. Pemanfaatan sabuk hijau waduk Jatigede secara kelembagaan dapat mensinergikan antara KTH dengan Pokwasmas yang memiliki kepentingan sama terhadap keberadaan sumber daya waduk. Semua sumber daya manusia dan kelembagaan yang terdapat di daerah sabuk hijau dapat dijadikan sebagai potensi pemberdayaan masyarakat dan kelembagaan dalam pemanfaatan sabuk hijau Waduk Jatigede. Bagan kelembagaan dalam perencanaan pemanfaatan sabuk hijau Waduk Jatigede (Gambar 5).

Pembangunan bendungan Jatigede telah selesai dan sudah mulai 
digenangi, ketinggian air baru mencapai $247 \mathrm{~m}$ dari rencana ketinggian maksimalnya di elevasi 260 meter (SNVT Proyek Pembangunan Waduk Jatigede, 2016). Setelah selesai proses penggenangan, akan ditunjuk suatu otorita pengelola bendungan Jatigede. Kegiatan pengelolaan bendungan menurut PP No. 37 Tahun 2010 tentang bendungan, adalah dilaksanakan pada bendungan beserta waduknya termasuk daerah sempadan waduk. Dalam pengelolaan waduk termasuk pemanfaatan daerah sabuk hijau diharapkan pihak otorita melibatkan dan memberdayakan masyarakat terutama yang terkena dampak (OTD) pembangunan Waduk Jatigede, sehingga mereka bisa mendapatkan kembali lapangan pekerjaan dan meningkatkan kesejahteraan hidupnya.

Gambar 5 adalah konsep kelembagaan dalam pemanfaatan daerah sabuk hijau Waduk Jatigede, otorita pengelola waduk sebagai pemilik dan penanggungjawab, dalam pengelolaannya harus inklusif. Forum MPJ (Masyarakat Peduli Jatigede) terdiri dari: Otorita Pengelola Waduk; Pemerintah Kabupaten Sumedang (instansi/dinas terkait) seperti Bappeda, Dinas Kehutanan dan Perkebunan, Dinas Perikanan dan Peternakan, Dinas Pertanian, Dinas Pariwisata dan Kebudayaan, Dinas Perdagangan Industri Koperasi dan UKM, Perum Perhutani; Lembaga Mitra (Bank, Kampus, Sekolah, Pesantren, Koperasi); Satuan Pelaksana Teknis (UPT Dinas /Instansi, Tenaga Teknis/Penyuluh lapang sebagai fasilitator/pendamping).

Di tingkat kebijakan dan pembinaan teknis kelembagaan dalam kegiatan pemanfaatan lahan sabuk hijau Waduk Jatigede, koordinasi lintas sektoral antara otorita pengelola dengan Pemkab Sumedang berkoordinasi dan bersinergi. Pemkab Sumedang memiliki SKPD (satuan Kerja Perangkat Daerah) yang berkaitan dengan pengelolaan lahan sabuk hijau, seperti Dinas Kehutanan dan Perkebunan, Dinas Perikanan dan Peternakan, Dinas Tanaman Pangan dan Hortikultura, Dinas Perdagangan Industri Koperasi dan UKM, Dinas Kebudayaan dan Pariwisata. Untuk pembinaan dan pendampingan teknis langsung di lapangan, dinas/instansi terkait mempunyai SDM pegawai, seperti: Penyuluh Kehutanan, Penyuluh Perikanan, Penyuluh Pertanian, dan petugas lapang lainnya yang relevan dalam pembinaan dan peningkatan sumber daya kelembagaan dan masyarakat di kawasan Waduk Jatigede. Di Desa Karang Pakuan terdapat kelembagaan Pesantren "Yayasan Kyai Demang Cipaku (YKDC)". Lokasi pesantren berbatasan langsung dengan daerah sabuk hijau. Kegiatan yayasan dan pesantren selain bidang pendidikan agama juga meliputi bidang pertanian secara luas, yaitu pertanian, kehutanan, perikanan dan peternakan. Secara kelembagaan pesantren YKDC berpotensi untuk 
diberdayakan dalam pemanfaatan sabuk hijau waduk Jatigede. Aspek agama dalam pendekatan komunikasi dan koordinasi kepada masyarakat/petani lebih memudahkan mengingat pesantren memiliki sumber daya manusia (SDM) yang terdiri dari : sekitar 100 jemaah laki-laki, 150 jemaah perempuan dari Majelis Ta'lim, dan santri 300 orang yang berasal dari dalam dan luar Kecamatan Darmaraja.

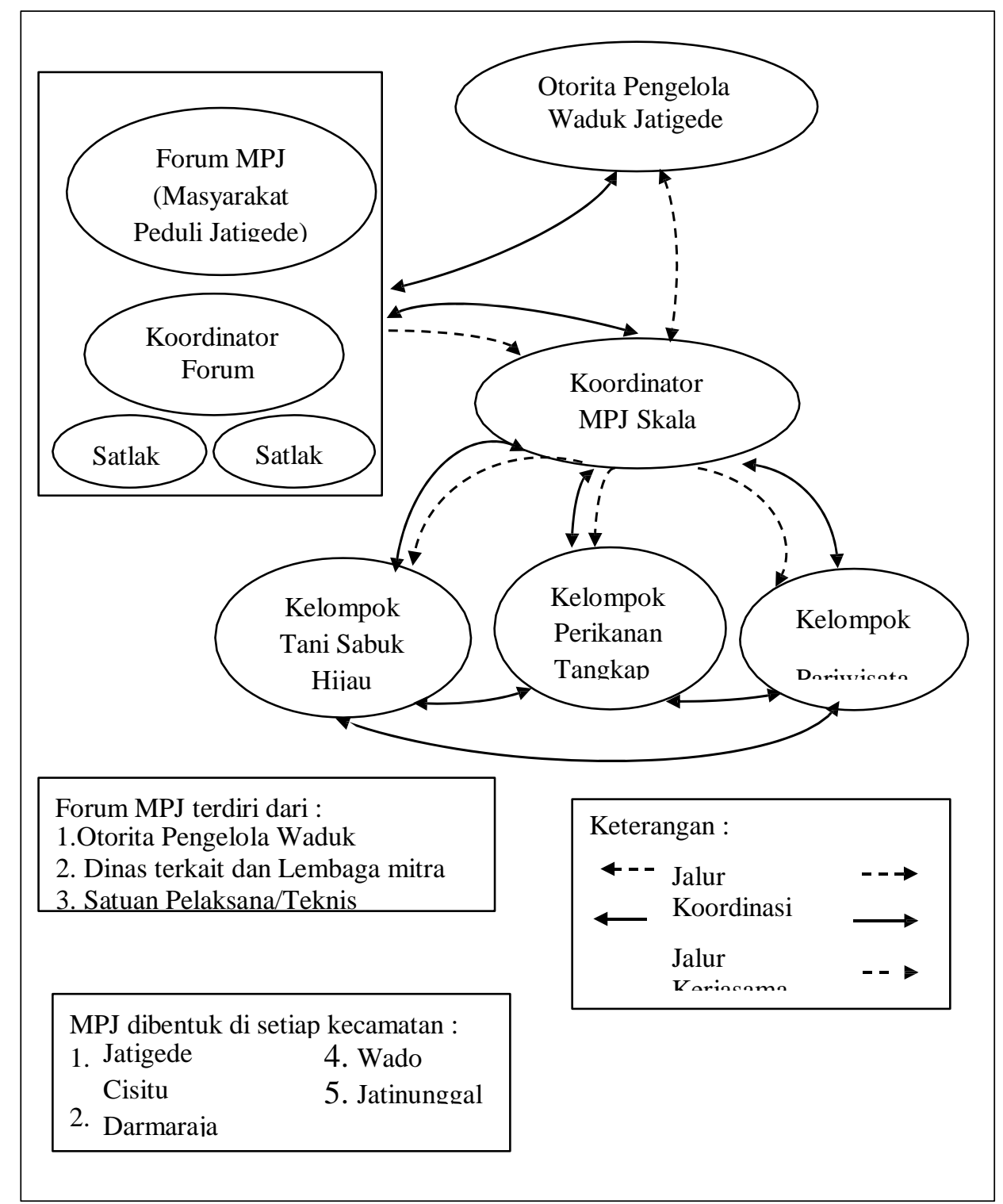

Gambar 5. Bagan Kelembagaan Pemanfaatan Sabuk Hijau Waduk Jatigede (Modifikasi Bappeda kabupaten Sumedang, 2016)

\section{KESIMPULAN}

Masyarakat di lahan sabuk hijau waduk Jatigede sebagian besar merupakan petani $(35,09 \%)$ dengan budidaya pertanian semusim. K egiatan lainnya adalah berjualan di tepian waduk Jatigede sebanyak $28,07 \%$, mencari rumput sebesar 
$21,05 \%$ dan aktifitas mengambil ikan (memancing) sebanyak 15,79\%. Perubahan kegiatan dari bertani menjadi aktifitas lainnya diperlukan suatu kelembagaan atau pelibatan para pihak untuk tujuan meningkatkan partisipasi masyarakat dalam pengawasan dan pengendalian sumber daya perikanan serta menumbuh kembangkan siswasmas (sistem pengawasan masyarakat) agar selalu tertanam tanggungjawab dan rasa memiliki terhadap sumber daerah sabuk hijau Jati Gede.

\section{DAFTAR PUSTAKA}

Arifman. 2015. Perencanaan Lanskap Kawasan Lahan Bekas Tambang Batu Bara Untuk Kawasan Wisata Alam Di Kawasan Kandi Kota Sawahlunto-PSMILUNPAD.

Daryanto. 2007. Analisis Geografis Terhadap Pemanfaatan Lahan Pasang Surut Bendungan Gadjah Mungkur di Kecamatan Nguntoronadi Kabupaten Wonogiri. E-Journal on-line. Melalui http://etd.eprints.ums.ac.id/2377/1/E100970083.pdf. [7/7/2016].

Djaenudin et al. 2003. Petunjuk Teknis untuk Komoditas Pertanian. Edisi Pertama tahun 2003. Balai Penelitian Tanah, Pusat Penelitian dan Pengembangan Tanah dan Agroklimat. Bogor.

Firmansyah, C. 2010. Perguruan Tinggi Membangun Desa : Kampung Mandiri Berbasis Biogas. Artikel on-line. http://peternakan.unpad.ac.id. [01/3/2017].

HD, Noni, dkk. 2012. Partisipasi Masyarakat dalam Perencanaan Sabuk Hijau pada Kawasan Waduk Jatibarang. Prosiding Seminar Nasional Pengelolaan Sumberdaya Alam dan Lingkungan, Semarang 11 September 2012. E-Jurnal on-line. Melalui :http://eprints.undip.ac.id.

Hardjowigeno, S. 2010. Ilmu Tanah. Cetakan Ke-7. Akademika Pressindo. Jakarta. Herdiawan, I, dan Krisnan, R. 2014. Produktivitas dan Pemanfaatan Tanaman Leguminosa Pohon Indigofera zollingeriana pada Lahan Kering. Wartazoa Vol. 24 No. 2 Th. 2014 Hlm. 75-82.

Kushartono, B, dkk. 2005. Profil Usaha Penggemukan Ternak Domba. Prosiding Temu Teknis Nasional Tenaga Fungsional Pertanian 2005.

Marsetyo. 2008. Strategi Pemenuhan Pakan Untuk Peningkatan Produktivitas dan Populasi Sapi Potong. Prosiding Seminar Nasional Sapi Potong. Palu. 24 November 2008.

Riduwan dan Kuncoro, E, A. 2011. Cara Menggunakan dan Memahami Path Analysis. Alfabeta. Bandung.

Saribun, S, Daud. 2007. Pengaruh Jenis Penggunaan Lahan dan Kelas Kemiringan Lereng terhadap Bobot Isi, Porositas Total, dan Kadar Air Tanah pada Sub-Das 
Cikapundung Hulu. E-jurnal on-line. Melalui : http://pustaka.unpad.ac.id. [7/2/2017].

SNVT Jatigede. 2013. Laporan Presentasi Zonasi Pemanfaatan Waduk Jatigede Dalam Rangka Mendukung Perekonomian Masyarakat Kabupaten Sumedang : Satuan Kerja Non Vertikal Tertentu Pembangunan Waduk Jatigede.

Suwartapradja, O, S. 2012. Sumber Daya Aquatic dan Penyerapan Tenaga Kerja (Studi Kasus pada Perikanan "KJA" di Perairan Waduk Cirata Jawa Barat) Volume 1 No.2 Agustus 2012. E-Jurnal on-line. Melalui http://jurnal.unpad.ac.id/jsp/article/download/4101/2449. [7/7/2016].

Warman, et.al. 2014. Studi Karakteristik Geologi Dalam Perencanaan Dan Penentuan Lokasi Bangunan Pelimpah Darurat Di Waduk Jatigede, Sumedang, Jawa Barat. Prosiding Seminar Nasional Kebumian Ke-7 Jurusan Teknik Geologi, Fakultas Teknik, Universitas Gadjah Mada, 30 - 31 Oktober 2014. 